\title{
The Transformation of Network Law Education in Universities and Colleges In the Era of Digital Economy
}

\author{
Yi Yang* \\ Department of Humanities and Social Sciences \\ Dalian University of Technology \\ ayangyi@163.com
}

\author{
Yuqin Zhou \\ Department of Humanities and Social Sciences \\ Dalian University of Technology \\ spledourr@163.com
}

\begin{abstract}
With the deepening of the information technology revolution and the advent of the era of the digital economy, the network has become a new technology carrier which is closely related to college students. However, there still exist a series of maladies that are not in line with the development of the times in the current situation. Therefore, it is necessary to promote the transformation of the network legal education in colleges and universities in the new period, which conforms to the social transformation and promotes the development of the rule of law. This paper first analyzes the necessity and related significance of the transformation of college students' network rule of law education, and uses the methods of comparative analysis, investigation and empirical analysis to analyze the defects and disadvantages of the network rule of law education in colleges and universities under the current situation. And on this basis, put forward targeted, forward-looking solutions to promote the process of socialist rule of law with educational transformation, and to implement the policy of ruling the country by law in an all-round way.
\end{abstract}

Keywords-Digital economy; Network-based Law education; Colleges and Universities; Transformation

\section{INTRODUCTION}

Since the beginning of the 21st century, with the deepening of the information technology revolution, the momentum of China's digital economy has been extremely rapid, the number of Internet users has grown to be the first in the world. There's no exaggeration to say that the network has become a new technology carrier that is closely related to people's lives, among which the group of college students is most affected. The fourth plenary session of the 18th CPC Central Committee proposed that we should promote the rule of law in an all-round way, and put forward the goal of carrying forward the spirit of the rule of law and building a culture of rule of law. The education of the rule of law in colleges and universities is one of the key links that cannot be omitted. It is in line with the spirit of all-round rule of law ${ }^{[1]}$, comply with the social transformation and promote the development of the rule of law.

The broad sense of network legal education in colleges includes two aspects: on the one hand ${ }^{[2]}$, it refers to the mode of legal education based on information technology such as network and new media; On the other hand, referring to such education, whose teaching content is about network-related knowledge of laws and regulations. In the era of digital economy, the transformation of network law education in colleges and universities should be based on the connotation of two aspects, analyzing the problems in the current situation, and seek solutions to conform to the development of the times.

\section{NECESSITY AND SIGNIFICANCE OF THE TRANSFORMATION}

\section{A. The network legal system is not perfect; the university} student netizens lack knowledge

The realization of "good governance by good law" advocated by Aristotle ${ }^{[3]}$ is the core goal of socialist rule of law construction, and the most important thing to achieve this goal is to establish citizens' belief in the rule of law. Under the current conditions, China's network-related laws and regulations are in the stage of development. The infringement of personal and property rights and interests in cyberspace, such as personal information rights, privacy rights, reputation rights, intellectual property rights, and so on, lack regulation and strong crackdown. There are also omissions in the protection of rights. Under such circumstances, the ugly behaviors such as "naked loan", network financial fraud, network plagiarism and others impact on teenagers' belief in the rule of law system. Therefore, it is necessary and urgent to carry on the transformation of network legal education in colleges and universities in the new period. It's beneficial to improve the efficiency of popularizing the knowledge of network law, to arm the self-protection mechanism of students' netizens, and even to stabilize the belief of the society in the rule of law.

\section{B. Stabilizing campus order and purify cyberspace}

Youth crime is the mainstream of cyber-crime. According to the investigation, in recent years, the network crime of our country presents the obvious low-age trend, taking the 16-18year-old as the main body, which has the great coincidence with the university student in the age. College students have advanced knowledge of network technology; young brains have rich creativity, so they tend to show themselves. Thus, they are likely catered to worship of "hacker", "technology house", leading to the unknowing cybercrime ${ }^{[4]}$. In addition, college students are still in the formation of values, emotional control ability is relatively weak; there are emotional, curiosity and other reasons to carry out illegal network behavior. 
Therefore to require college students to master the laws and regulations related to the network is conducive to understanding the boundary of the violation of the law, thus standardizing their own behavior, reducing the occurrence of network malignant events, stabilizing the order of the campus, and purifying the cyberspace.

\section{It is the campus embodiment of all-round rule of law,} which is conducive to the cultivation of core values

The fourth plenary session of the 18th CPC Central Committee put forward the historic task of comprehensively promoting the rule of $\operatorname{law}^{[5]}$. After that, Office of the leading Group on Network Security and Informatization of the Central Committee, in response to the policy, organized symposiums, and determined the direction of the development of the Internet in the new era. The policy orientation puts forward the new requirement to the network rule of law education in colleges and universities, changes the education thought, enhances the actual effect of the network rule of law education, and is the campus embodiment of the all-round rule of law, which is helpful to accelerate the network space legalization process.

\section{The Dilemma OF THE NETWORK RULE OF LAW EDUCATION IN COLLEGES AND UNIVERSITIES IN DIGITAL ECONOMY TIMES}

\section{A. The form of network education ruled by law is old and the utilization rate of new carrier is low}

Most of the college students are in the 18-year-old 24-yearold stage, generally have the psychological characteristics of strong curiosity, high acceptance, love of new things ${ }^{[6]}$. Therefore, widening the form of education, using multimedia, digital technology and other new carriers is bound to be a major trend in the reform of law network education. However, on the one hand, there are some defects in the current network rule of law education mode in colleges and universities in our country, such as the old form and the single kind of teaching carrier, there are few attempts to create new forms, and still more forms are waiting to be excavated. On the other hand, the existing new carriers have the disadvantage of low utilization rate, for example, on the network education platform such as MOOC, university state and so on. There are fewer courses and more scattered knowledge points in the course. Students use this kind of platform more in order to meet the requirements of the assessment, so it is superficial and ineffective ${ }^{[7]}$.

\section{B. College netizens lack awareness of rights and lack realization of illegality}

On the one hand, the awareness of the rights of the netizens in colleges and universities is relatively indifferent. In the face of new forms of infringement, due to the lack of legal knowledge, it often appears that they are unable to realize that their rights and interests are impaired. Or even they have consciousness, they do not know how to take relief measures to safeguard rights. For example, in the process of online shopping, business fraud and breach of trust, they did not know how to use the Consumer Rights and interests Protection Act and the contract Law to protect their rights. In the face of network language violence and news distortion, they do not know how to safeguard their personal rights and interests. On the other hand, as mentioned above, due to the advantages of information technology among college students themselves and the lack of awareness of illegality, the concept of rule of law does not exist strongly. Hacker attacks, emotional crimes and other network violations often occur in this group. It can be seen that speeding up the transformation of the rule of law education system in colleges and universities in the digital economy era and establishing a set of scientific guiding and management mechanisms has become an urgent matter of urgency for the current law education, and in this process, the most important thing is to enhance the awareness of the rights and obligations among college students, and to strengthen their understanding of illegal boundaries.

\section{The concept of network education under the rule of law is backward, and there is a lack of professional teachers}

The educational idea of colleges and universities is supposed to conform to the development of the times, and the network education of rule of law, also needs to cater to the trend of the digital economy era. In the current education concept of network law in our country, we pay more attention to the prohibition regulation and the popularization of illegal acts, but easily ignore the cultivation of the concept of rights. When we introduce the rights of citizens in the cyberspace, we also pay more attention to substantive rights such as property rights. However, in the highly developed digital economy era of information technology industry, the protection of intellectual achievements has become an industrial and economic value behavior. Therefore, changing the concept of legal education is a major trend of the transformation of network legal education in the new period ${ }^{[8]}$.

In addition, the network rule of law education teachers lack of professional literacy, is also a major disadvantage under the current conditions. The use of open-ended teaching platform, such as Muchcourses, leads to more complicated students and higher requirements for teachers in the process of comparing with related courses in foreign countries. At the level of entity curriculum, the course of rule of law education in colleges and universities is arranged in the course of ideological and political education. As a compulsory course, "ideological and moral cultivation and legal basis" is an important and even main part of the rule of law education in colleges and universities. However, only a small number of teachers in charge of the curriculum education have professional legal literacy, and they can only have a brief taste of the legal knowledge related to the course in a timely manner. Dabble, let alone carry on the network legal system education that keeps pace with the times, and has the life significance.

\section{THE COUNTERMEASURES OF THE TRANSFORMATION OF THE NETWORK LEGAL EDUCATION: IN THE NEW PERIOD}

A. To develop a new form of education based on network rule of law and enrich the types of educational carriers.

In the age of information network, new media is characterized by high interaction, low cost, strong permeability and so on, and its traffic effect can't be underestimated. Under the current situation, the most common carrier of web-based curriculum is MOOC. However, the utilization rate and actual efficiency of this form are rather limited. There are many disadvantages in web-based courses, such as a loose 
distribution of knowledge points, a lack of scientific curriculum system, and so on. In many cases, it is only used as a way for teachers and students to cope with the assessment, but fails to give full play to its inherent advantages as a web-based teaching platform. In the transformation of network rule of law education in colleges and universities in the new period, we should pay attention to the flow effect of network, new media and other technologies. We should not only improve the teaching efficiency of the platform, but also develop all kinds of new forms of teaching carriers, combine WeChat official account, Weibo, short video of rule of law education, mobile phone APP and other forms to organically combine pictures, articles, sounds, and images. Only in that way can we activate the teaching form, widen the teaching space and spread the knowledge of network rule of law by the combination of case and rule of law.

\section{B. Paying attention to the effectiveness of the rule of law education; popularizing the concept of operational legal system $^{[9]}$}

The purpose of popularizing the law is to apply it. In the new period, the network education of rule of law should pay attention to the effectiveness, and the content of education should be closely related to the daily life of college students. Under the circumstances that ideological and political education is arranged in limited hours and teaching tasks are heavy, the network-based rule of law education in colleges and universities should carry out the aim of "not having to study extensively, but want it to be useful," and properly abandon red tape and the rules and regulations that are not strong in practicality. Specifically, on the one hand, it is necessary to popularize the law which is closely related to the actual life of college students. Laws, regulations and policies to deal with infringement in the field of cyberspace, such as the articles on personal rights of citizens and the corresponding relief forms in the General principles of Civil Law 100-102, so as to facilitate college students who suffer the tort of privacy in cyberspace, when face the damage of the right of portrait and reputation ,they can effectively protect their rights; The regulations on Information Network Communication have made more specific provisions on the determination of infringement of network intellectual property rights, such as the way of liability undertaking and the way of relief. Understanding the regulations is helpful for students to correctly define the infringement of network copyright, which is a benefit to regulating their own behavior, and protecting their works. On the other hand, we should, in combination with relevant cases, give a detailed explanation on the punishment mechanism and ways of safeguarding rights in the form of network loans, telecommunications fraud, and other forms of cybercrime. In order to improve students' ability to solve practical problems, the knowledge of laws and regulations related to the network exists in the mind of students in a concrete form.

\section{Introducing the New idea of Network Rule of Law} Education to accelerate the improvement of Teachers' team quality

In the course of the transformation of the network rule of law education, the most fundamental thing is to renew the education idea, introduce the network information thinking into the network rule of law teaching idea, and improve the ability of the university netizens to distinguish the advantages and disadvantages in the network space, to safeguard the rights and interests and to fulfill their obligations. In particular, we should pay attention to the cultivation of the awareness of network spiritual rights, such as the right to personal information and intellectual property rights, so as to better protect the personal rights and intellectual achievements of netizens in colleges and universities, so as to promote the deepening of the information technology revolution. In that way, we will better implement the strategy of rejuvenating the country through science and education and strengthening the country with talent.

In view of the low quality of the online legal education teachers' team, on the one hand, we should strengthen the training of teachers in ideological and political courses on legal knowledge. On the other hand, we can hire professionals such as lawyers to enter the classroom as special teachers. By doing this, we can strengthen the connection between network legal education and the life of netizens in colleges and universities, and to improve the effect of education, the problems of network infringement and network crime in practice are explained.

\section{CONCLUSION}

In the era of the digital economy, the new economic model of cyberspace and the mode of social communication all need higher awareness of the rule of law among netizens in colleges and universities. At the same time, ruling the country by law in an all-round way puts forward higher requirements for legal education on campus. The high level of cybercrime took away a stable school order. of colleges and universities, and the lack of intellectual achievements in cyberspace restricts the upgrading of the industry. A series of contradictions indicate that the transformation of network legal education in colleges and universities has become an inevitable trend. However, under the current conditions, there are a series of drawbacks that hinder the transformation of the network rule of law education in China, such as the single form of education, the backward educational concept, the lack of professionalism of the teachers' team and so on. In the form of education, the popularization and practicability of the new carrier are deficient When it comes to the concept of education and the strength of teachers, there are two aspects of the dilemma. On the one hand, the traditional prohibited legal popularization education can't meet the objective requirements of promoting the prosperity of the network industry. On the other hand, the network rule of law education lacks a professional education team, leading to the weak effectiveness of the rule of law education in colleges and universities. In the course of the transformation of network education of rule of law in colleges and universities, we should pay special attention to the above problems and seek solutions with pertinence, foresight and maneuverability. This paper puts forward some methods to solve this problem, such as activating teaching form, renewing educational idea, recruiting external professional teachers, and so on, which can be used as some suggestions in the way of the transformation of network legal education in colleges and universities. 


\section{ACKNOWLEDGMENT}

I would like to express my sincere thanks to many classmates for their valuable suggestions during the writing of the thesis, to my colleagues who gave me a lot of support and help during the work and to all my good teachers and friends who cared, supported and helped me. Thank Yujun Feng, Deng Yefen and other scholars for giving me many opinions and inspiration. Besides, I would like to express my heartfelt thanks to all the experts who have taken time out of their busy schedule to review this article and put forward valuable opinions ${ }^{[10]}$. Finally, I sincerely thank all the scholars cited in the references.

\section{REFERENCES}

[1] Shi Haoxu. A brief analysis of network legal education for college students in big data era [J]. Read and write (Journal of Education and Teaching), 2016, 13 (02): 8288.

[2] The role and Challenge of big data to Education and the trend of Educational Reform-A Review of the latest Research Progress in the era of big data [J]. Hu Bicheng, Wang Zulin. Modern university education $2015(04)$
[3] Big data's Perspective Analysis of Learning Reform-interpretation and Enlightenment of the report "promoting Teaching and Learning through Educational data Mining and Learning Analysis" in the United States [J]. $\mathrm{Xu}$ Peng, Wang Yining, Liu Yanhua, Zhang Hai. Journal of distance Education. 2013 (06)

[4] The development stage and pattern characteristics of the rule of law in China [J]. Feng Yujun. Journal of Zhejiang University (Humanities and Social Sciences Edition). 2016 (03)

[5] Thoughts on legalization of network ideological and political education in colleges and universities [J]. Deng Yefen. Ideological and theoretical education. 2015 (08)

[6] A study on the Evolution of Chinese Citizen's Law Popularization Education [D]. Gao Xuemin. Fudan University 2014

[7] A study on the current situation and educational countermeasures of the legal norms of college students' network behavior [D]. Liu Xiaoyan. Xi'an University of Science and Technology 2012

[8] Measures to integrate moral education into legal education courses in colleges and universities [J]. Xu Xiaojing. Journal of Hunan City College (Natural Science Edition). 2016 (03)

[9] Moral and legal education of teenagers under socialist core values [J]. Dean. Journal of Xi'an University of Arts and Science (Social Science Edition). 2016 (01)

[10] Promote the thought of rule of law, cultivate and strengthen the education of legal system in colleges and universities [J]. Yongchunmei. Journal of Jilin province economic management cadre college. 2016 (03) 